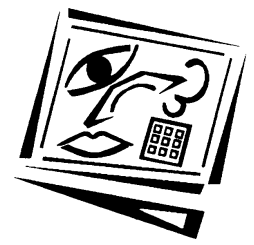

\title{
A dialogic approach to online facilitation
}

Jennie Swann

Auckland University of Technology

An Outstanding Paper Award recipient, ascilite Auckland 2009 Conference

Social construction of understanding has long been a significant underlying principle of learning and teaching, and while there are many models for the design of online activities to promote this, there are considerably fewer models for the facilitation of such dialogue. This paper examines some of these facilitation models from the point of view of a university tutor seeking to encourage social construction of understanding through online dialogue, and proposes an alternative which extends the principles of community of inquiry theory. It unpacks conceptions of community and dialogue in the context of learning and teaching and describes a research project whose purpose is to develop and iteratively test a professional development intervention, which will help university tutors to facilitate a dialogic approach to learning online.

\section{Introduction}

If we declare that we value different perspectives, as a commitment to dialogic literacy will lead us to do, perspectives of those new to a discipline or to academia, perspectives different from ours culturally, then we must develop practices which also value these differences. Such practices in turn commit us to a dialogic theory of learning that sees knowledge not only as the product of disciplined inquiry, where well-established conventions allow the accumulation of co-ordinated data, but also as the product on ongoing discourse, where different perspectives draw on the power of the negative to lead to a higher integration of understandings. Practices that value difference and a dialogic approach to language and learning are not easy to formulate or to employ in our academic environment (Cooper, 1998, p. 82).

The proliferation of social software tools has brought with it an escalation of informal learning through online dialogue among mainly young people, many of whom are also university students. Downes (2004, para. 35), among others, has for some time referred to the Internet as a meeting place where dialogue is replacing information publishing and retrieval. Paradoxically however, students are often resistant to attempts to integrate such dialogue into their formal learning. Dirkx and Smith (2004) in a study of graduate students in a fully online course found that, while their students embraced the principle of learning through working in groups, they found it extremely difficult in practice to achieve consensus, perhaps partly because of their competitive approach to assessment. The focus of this paper is on the dialogue itself in a university learning environment, and on the development of facilitation techniques which will encourage it to flourish, rather than on the affordances of the technological tools available. 


\section{Dialogue and learning}

Learning through dialogue with others has a long history. Plato learned from Socrates through dialogue and argumentation. Dewey (1910/1991) argued that learning is most effective when it is situated in an authentic, real world context and that this context is social as well as physical. Vygotsky's (1986) zone of proximal development theory has been interpreted (by Lave \& Wenger, 1991, among others) to mean that students learn better collaboratively because it is dialogue with others which pushes them into this "societal" space between the everyday behaviour of the individual and social practice (p. 48). This space is dynamic in that it is itself changing, and influenced by the individuals in it, through "the negotiated character of meaning" (p. 33). Piaget, too (1962, 1972), has been influential in the development of socially constructivist pedagogy, although his stages of development may be too rigid for application in all cultures. The educational philosophies of these three, Dewey, Vygotsky and Piaget, underpin many pedagogical theories of online learning. Swan and Shea (2005) identify three main themes of learning theory which are distinctively social. These are that:

- cognition is situated in particular social contexts (Brown, Collins, \& Duguid, 1989; Lave \& Wenger, 1991);

- knowing is distributed across groups (Cole, 1991; Perkins, 1993); and

- learning takes place in communities (Lipman, 2003; Scardemalia \& Bereiter, 1996; Wenger, 1998).

These themes underpin many of the prevailing theories of online pedagogy such that these approaches require students to engage with their course content through discussion with their peers. This has proved difficult to achieve online (Kreijns, Kirschener \& Jochems, 2003; Pawan, Paulus, Yalcin \& Chang, 2003; Swan, 2004). There is no lack of models for the design of learning and collaborative activities (see e.g. Palloff \& Pratt, 2005; Reigeluth, 1999) and a great deal has also been published in the form of research and case studies on the facilitation of social and collaborative learning online. However as Reeves writes, "Educational research is usually published in refereed journals that are unread by the vast majority of practitioners" (2006, p. 58). There is a need for a practical approach which is readily usable by online tutors and this paper provides a literature review of the alternatives and describes a research project which suggests a new approach.

\section{Why do we need a new approach?}

Salmon $(2000,2002)$ provides perhaps the only model which is specifically designed to help tutors to facilitate discussions online and many have found it extremely effective as a starting point. However, Stages 1 and 2, learning to use the technology and online socialisation, are both in practice revisited repeatedly throughout the life of an online discussion (Swann \& Sevelj, 2005). The dialogue often stalls at Stage 3, information sharing or "cumulative dialogue"; the true collaboration of Stage 4 has proved more elusive (see e.g. Chai \& Khine, 2006). From a tutor's perspective, many of the issues of facilitating learning dialogue online are much the same even when different tools are used (Elgort, Smith \& Toland, 2008; Forte \& Bruckman, 2007; Fountain, 2005; Guzdial, Ludovice, Realff, Morley \& Carroll, 2002; Notari, 2006). A non-linear model may be more realistic. 
Baker, Jensen and Kolb's (2002) conversational model focuses on "a space where conversation can occur" (p. 64). They propose five dialectical dimensions of this space which need to be engaged simultaneously in order for learning to occur. These are:

- the integration of concrete experience and abstract thought;

- the integration of reflection and action;

- the spiral nature of these two;

- the relationship between separate and connected knowing; and

- the balance between collaboration and leadership.

However, on closer examination it appears that this is another way of looking at Kolb's familiar experiential learning cycle (Kolb, 1984). It could be argued that the first two of these dimensions restate this learning cycle and there are category differences which cause a poor fit with the others. For example, dialectic dimension three could be seen as a description of an ideal relationship between dimensions one and two, while dimension four might be a different way of categorising dimensions one and two.

Kolb's experiential learning cycle has been in regular use for over 20 years and it has proved an effective basis for some types of learning, e.g. skills-based workshops. However, there has been criticism of its theoretical underpinnings. Oxendine, Robinson and Willson (2004, para. 30) argue that "the concepts outlined by Kolb are too ill-defined and open to various interpretations and that the ideas he presents are an eclectic blend of ideas from various theorists that do not fit logically". There are difficulties too with the notion of concrete experience, since it does not really include the social aspects of experience. Also in practice university students often "experience" something by reading about it; this is two levels of abstraction (speech and text) away from the concrete (Laurillard, 2002b). Further, Kolb cites Dewey $(1910 / 1991)$ in support of his reflection/action dimension of learning whereas in fact Dewey believed that we do not generally reflect on our experience unless it has produced a noticeable contradiction (Oxendine, et al., 2004, para. 24).

Laurillard $(1993,2002 a)$ has proposed a conversational model of learning based on a phenomenographic approach, on the grounds that this is more democratic. Democratic is used to mean "giving full representation to students' as well as tutors' conceptions... The learning process must be constituted as a dialogue between tutor and student" $(1993$, p. 94). Laurillard's conversational model has been criticised on the grounds that the community of practice concept of progression from novice to expert which it entails is extended too far (Wise \& Quealy, 2006). While it is appropriate for fostering research communities it is perhaps less helpful as a model for university teaching and learning. Wenger's (1998) Community of Practice model is based on his work with large industrial firms and in this environment communities grow, mature and die over a period of years. Membership of a community is voluntary and changes during the community's life cycle as the original core moves on and peripheral members gain expertise and move towards the centre. In a modular university system, a onesemester course does not allow sufficient time for such a community to form, let alone mature, and students are not generally given the option of not participating (Carusi, 2006; Wilson, Ludwig-Hardman, Thornam \& Dunlap, 2004).

There has been some confusion in online learning research literature between Community of Practice and Community of Inquiry theory. The Community of Inquiry model is based not on the Community of Practice model but, at least in part, on 
Lipman's work with children (2003) in which "tutor and children collaborate with each other to grow in understanding, not only of the material world, but also of the personal and ethical world around them" (Wegerif, 2007, p. 139). Garrison, Anderson and Archer used Lipman's model, and their own research into online learning in the 1990s, to develop their Community of Inquiry model (Garrison, 1997; Garrison, Anderson \& Archer, 1999). This is often shown as a Venn diagram in which the sets of cognitive presence, social presence and tutor presence overlap to create the educational experience.

A significant amount of research has been done on the various aspects and implications of this model for online learning. There has been research on teaching presence, particularly teacher immediacy in design and setup (e.g. Melrose \& Bergeron, 2007), and also on ways of supporting social presence (Tu, 2002; Weaver \& Albion, 2005). Research has been done on social identity (Merchant, 2006), group work (Weterman, 2004), teamwork (Davis, 1993; Meeuwsen \& Pederson, 2006), collaboration and cooperation (Allen \& Lawless, 2003; Cameron \& Anderson, 2005), participation (Chai \& Khine, 2006; Williams, 2003), and peripheral participation (Hung, Chen \& Koh, 2006). In the area of cognitive presence, there has been work on reflection (Stefani, 2004), schemata (Grossera \& Lombard, 2008), cognitive load (Hron \& Friedrich, 2003), also on teaching thinking skills (Duron, Limbach \& Waugh, 2006; MacKnight, 2000). A review of 252 reports from 2000-2008 which referenced Garrison, Anderson and Archer's community of inquiry framework (Rourke \& Kanuka, 2009) indicated "that it is unlikely that deep and meaningful learning arises in CoI" (p. 19). There was a rapid response to this from Garrison and others (Aykol, et al., 2009), but it is interesting to note that this fundamental criticism came from two members of the group who originated this model. Another point of interest is that, while the focus of the Garrison, Anderson and Archer model is the people conducting the dialogue, that of Lipman's model is upon the dialogue itself.

\section{A dialogic focus}

Wegerif (2007) suggests a dialogic model which is also based on Lipman's (2003) Community of Inquiry work. Working with children on projects to teach them thinking skills and, unsatisfied with his original conclusions, he re-analysed and reinterpreted his data in a search for a better explanation of "the mystery of how people actually solved the problems together" (p. 56). In a series of experiments to test the approaches taken by groups of 8-11 year-olds to solving spatial problems, students were tested on sets of problems and then retested on the same sets after class work designed to open up space for reflective dialogue. Their dialogue was recorded and compared in order to find out which aspects of the dialogue helped them to solve the problems successfully. Group members suggested ideas and solutions, sometimes struggling to express them in words, but they also explored a number of different perspectives in an inclusive way, encouraging and supporting the dialogue, before reaching a consensus. In addition, some students changed their minds as the dialogue proceeded. Following arguments that language and thought are closely intertwined (Bakhtin, 1981; Buber, 1947; 1998; Vygotsky, 1986), Wegerif derived a model from Lipman's which brings dialogue to the fore. It can be represented as shown in Figure 1.

Although reflective dialogue has strong connections with Lipman's notion of multidimensional thinking, in that reflection allows synthesis, there may be difficulties with the use of this term as it has been used elsewhere with different connotations (Brookfield, 1995; Schon, 1983). 


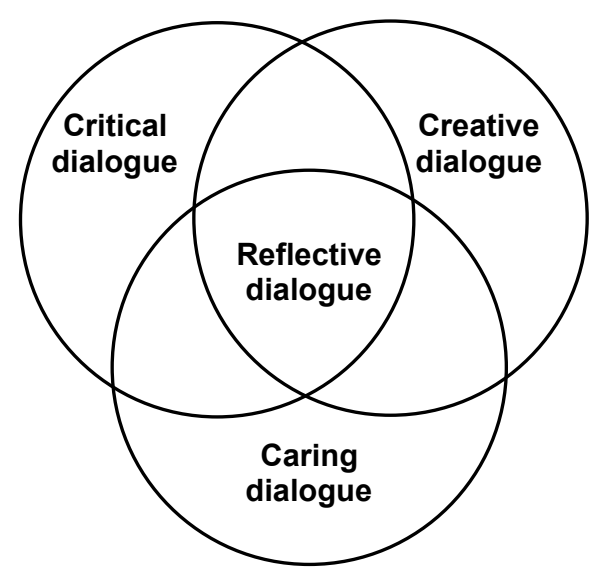

Figure 1: Three dimensions of dialogue, adapted by Wegerif (2007) from Lipman (2003)

Critical thinking has become embedded in our culture and in most of our theories of education and it is the kind of thinking which is often assessed at university level. Fundamental to it is the Socratic idea that two things cannot occupy the same place at the same time and this causes it to be competitive as cases are made for alternative hypotheses. This approach has served us well for more than 2000 years and it is vital to a Western legal system. Yet students often find this kind of thinking difficult to express when they are learning something new, perhaps because emerging ideas are very vulnerable to criticism. People are generally unwilling to say something which they are not sure of to people they cannot see and hardly know; trust is an important factor (Coppola, Hilz \& Rotter, 2004; Hurst \& Thomas, 2004; Wilson, et al., 2004). Following Lipman, Wegerif (2007) argues that it is beneficial to learning for emerging ideas to be able to flourish in a dialogic space, in tension with other perspectives, without having to make and justify a case at the outset.

Instead of trying to build trust in the competitive environment of a Socratic dialogue, the dialogic space is broadened to include other types of dialogue which contribute to the development of understanding yet which are easier for students to express. Creative dialogue opens up a reflective space in which issues can be explored with encouragement and trust. One of the skills to be learned here is that of asking intellectually fruitful questions. Another technique is "thought shower" - similar to but perhaps less intense than brainstorming - in which even implicit judgement is suspended. Creative thinking, or dialogue, is not the same as creativity, which is often associated with art and design, yet it appears to have an important role in discovery. Koestler (1969) documents the work of a number of scientists, among them Maxwell, Pasteur and Einstein, whose discoveries were often the result of creative leaps of intuition followed, rather than preceded, by logical reasoning. Cutting edge scientific discovery is different from learning that which is already known to others. Yet the process may be seen as similar, "For man cannot inherit the past, he has to recreate it" (Koestler, 1969, p. 268). Koestler also describes the concept of "ripeness" for discovery, in which a researcher is so steeped in the relevant knowledge that there is ample fuel for the creative spark. Perhaps in the same way student discussion which has been cumulative in nature may provide fuel for an intuitive spark of understanding. Indeed 
Wegerif and his colleagues have found some evidence that this can occur (de Laat, Chamrada \& Wegerif, 2008).

A third aspect of this reflective space is caring dialogue, which is also not critical in any way. It aims not only to allow, but actively to draw out the distinctiveness of others' arguments and ideas with respect and humility. Buber calls this intersubjectivity (1947, Section II), "each of the participants really has in mind the other or others in their present and particular being, and turns to them with the intention of establishing a living mutual relation between himself and them." This is very important in the multicultural classes of today. The focus is on listening and understanding (Bakhtin, 1986), or reading and understanding in an asynchronous online environment. Caring thinking also includes caring about the topic or subject (Lipman, 2003, p. 262), which Sharp (2004) calls pedagogic caring, as much as about the other participants in the dialogue. These are not separate thinking skills, nor are they hierarchical, but dimensions of reflective dialogue (Wegerif, 2007, pp. 152-155). This is a dialogic model and as such the process is at least as important, if not more so, than the product. Knowledge is not stable. It continuously changes, develops and, sometimes, contradicts itself. Therefore the notion that students' "naive" perspectives are impediments to learning is rejected. These perspectives are encouraged as productive sources of learning (Cooper, 1998).

Lipman has tested his model empirically, originally in the 1970s in the Philosophy for Children project (Lipman, 2003), but it has been in continuous use since then (see e.g. http://www.p4c.com/). The conviction that a Community of Inquiry approach can bring about "deep and meaningful learning" (Rourke \& Kanuka, 2009, p. 19) underpins a project in which reflective dialogue and its supporting structures was put into practice in a face to face environment with children (Dawes, Mercer, \& Wegerif, 2006). It also underpins part of the research in the ARGUNAUT Project, a collaboration of seven European universities and research centres, whose goal is to provide an approach and software tools to help tutors to support online synchronous discussion among small groups of students (Asterhan, et al., 2008; de Laat \& Wegerif, 2007). Support for the dialogic process involved the use of "argument scripts" (Dillenbourg \& Jermann, 2006) of two types, micro-scripts and macro-scripts. Micro-scripts often take the form of sentence stems or buttons which are used to guide students as they construct arguments. In the ARGUNAUT Project a software application called Digalo was used. Digalo provided a set of shapes from which students could choose to signal the type of contribution they were making - question, claim, counterclaim, reason etc. Macro-scripts model an approach to a group's collaborative process. Interestingly, Wegerif suggests in one of the final ARGUNAUT Project reports that the latter are far more effective (Wegerif, et al., 2008). Examples of macro-scripts include the Belbin approach to team make up, SWOT analyses for decision making, appreciative inquiry or de Bono's six thinking hats. There are many such models, especially in the field of business, most of which are designed to produce a decision or solution.

Although they have been developed quite separately, there is an overlap between the theories of Community of Inquiry and Inquiry Based Learning which might prove fruitful for the development of a workable approach. While an inquiry may not reach a definite conclusion it must, in order to sustain the interest of the participants, make progress towards something of substance, e.g. truth (Gardner, 1995). Without this, the dialogue has no direction. An Inquiry Based Learning project at the University of Sheffield in the UK has produced a matrix containing four modes of student inquiry: 
- Identifying (information responsive): Students explore the knowledge base of the discipline in response to questions or lines of inquiry framed by teachers ("What is the existing answer to, or current state of knowledge on, this question?")

- Pursuing (information active): Students explore a knowledge base by pursuing their own questions and lines of inquiry ("What is the existing answer to, or current state of knowledge on, my question?")

- Producing (discovery responsive): Students pursue open questions or lines of inquiry, framed by tutors or clients, in interaction with a knowledge base ("How can I answer this open question?")

- Authoring (discovery active): Students pursue their own open questions and lines of inquiry, in interaction with a knowledge base ("How can I answer my open question?") (Levy, 2009).

This could provide the foundation for a macro-script, or set of macro-scripts, to support the facilitation of online dialogue. The author is currently developing and iteratively testing a set of macro-scripts to be used as part of a professional development intervention which will support university tutors in facilitating asynchronous reflective dialogue online through an inquiry approach which is dialogic in nature. A design based research (DBR) approach is being taken so that the intervention, which is currently face to face, can be tested and refined to a point where an online version can be shared more freely.

\section{Researching a dialogic approach}

Wang and Hannafin (2005, p. 5) define DBR as "a systematic but flexible methodology aimed to improve educational practices through iterative analysis, design, development and implementation, based on collaboration among researchers and practitioners in real world settings". There are a number of variants of this approach and this research project takes van den Akker's (1999) development research approach, whose methods include:

- Literature review and expert consultation;

- Working with research participants to develop and refine the intervention;

- Systematically documenting, analysing and reflecting on both the process and the outcomes;

- Testing interventions empirically; and

- Generating principles as heuristics.

Although an online version of the professional development intervention is planned, it is very different from the technology based learning and instruction systems often associated with this form of research and as such is intended to avoid the "under conceptualised and over methodologised" critique often levelled at it (see e.g. Dede, 2004). This intervention is based on a Community of Inquiry approach which has been extensively researched (see above) in a face to face environment with younger students, and also in a synchronous online environment with university students. Therefore the present research will focus on the development of ways of operationalising it for university tutors facilitating dialogue in an asynchronous online environment.

Another criticism of DBR is that far more data is routinely gathered, through repeated interviews, surveys and video recordings, than is justified by the conclusions drawn from their analyses. However, as Dede (2004) points out this is not intrinsic to DBR. 
Certainly this research project attempts to find "elegant collection and analysis strategies" (Dede, 2004, p. 108). For example, discourse analysis will be used, rather than the content analysis often applied to discussion forum postings, in order to provide a richer picture of the inter-posting and inter-participant cohesion and coherence of text as well as intersubjective elements of the dialogue. A further issue is the definition of conditions for success. In this project these involve not only measures of student learning and sense of community but also teacher perceptions of the artefact's usefulness and usability. There are other criticisms of DBR; many of these reflect the issues of quantitative versus qualitative research and will not be addressed here.

The research involves three iterations, each informing the revision of the intervention for the next. The first of these, conducted in 2009, was with tutors and students engaged in a fully online, distance professional Masters program in adult literacy and numeracy education. Perceptions of both tutors and students were that there was a strong sense of community within the group. However, as every teacher knows, sometimes this owes more to the synergies among the personalities within the student group than to anything the teacher did. The adult literacy and numeracy community in New Zealand is relatively small and close knit so there is a good chance that many of the students knew, or knew of, each other before they joined the program. The second iteration will involve a much less cohesive group of students in the field of health care. Student feedback on last year's offer of that program indicated that many of the students expected their learning to be teacher centred and to consist of "facts and skills". This should provide a much more challenging test of this aspect of the approach.

Discourse analysis of some of the discussion postings was based on categories developed in the ARGUNAUT project (Wegerif, et al., 2008): critical reasoning, creative or dialogic reasoning, dialogic engagement and moderation (which could be done by either the tutor or a student). A preliminary analysis showed a high incidence of dialogic engagement, perhaps for the reasons suggested above, and a low incidence of critical reasoning. Since the discussion was of a set of readings on a particular issue, it is possible that critical reasoning would be found mainly in the readings themselves and that students would hesitate to question such assertions. The Sheffield University inquiry based learning framework (Levy, 2009) could help in the unpacking of this, as it distinguishes clearly between teacher-led and student-led inquiry.

\section{Conclusion}

This paper has provided a review of the literature in the facilitation of online learning dialogue in a search for a means of supporting university lecturers and tutors who use online communication tools such as discussion forums, blogs and wikis in their teaching. It has also described the early stages of a research project to develop and test a professional development artefact which will achieve this. A dialogic, inquiry based approach has been outlined and the development based research method described. A DBR process may be considered too long for a $\mathrm{PhD}$ project, but Herrington, McKenney, Reeves and Oliver (2007) have argued that it is possible. The research is likely to continue beyond the degree program and so this should be regarded as a work in progress. At this stage, student and tutor response to the approach is positive. Further research will indicate whether or not this optimism is justified. 


\section{References}

Allen, J. \& Lawless, N. (2003). Stress caused by online collaboration in e-learning: A developing model. Education + Training, 45(8/9), 564-572.

Asterhan, C., Hever, R., Schwarz, B., Mishenkina, M., Gil, J., Penso, H., et al. (2008). Argunaut deliverable D6.2: Evaluation report on the pedagogical content of the Argunaut system Preliminary findings. [viewed 12 Aug 2008] http:/ / www.argunaut.org/shared-space/wp6/deliverables\%20and\%20milestones/Microsoft_Word_-_d6.2final.pdf

Aykol, Z., Arbaugh, J. B., Cleveland-Innes, M., Garrison, D. R., Ice, P., Richardson, J. C., et al. (2009). A response to the review of the community of inquiry framework. Journal of Distance Education, 23(2), 123-136.

Baker, A. C., Jensen, P. J. \& Kolb, D. A. (2002). Learning and conversation. Conversational learning: An experiential approach to knowledge creation (pp. 2-11). Westport: Quorum.

Bakhtin, M. (1981). The dialogic imagination (C. Emerson \& M. Holquist, Trans.). Austin: University of Texas.

Bakhtin, M. (1986). Speech genres and other late essays. Austin: University of Texas.

Brookfield, S. D. (1995). Becoming a critically reflective teacher. San Francisco: Jossey-Bass.

Brown, J. S., Collins, A. \& Duguid, P. (1989). Situated cognition and the culture of learning. Educational Researcher, 18(1), 32-42.

Buber, M. (1947). Between man and man. London: Kegan Paul.

Cameron, D. \& Anderson, T. (2005). Collaborative learning activities using social software tools. [viewed 18 Jul 2006 at http:/ / www.writely.com/View.aspx?docid=ag9j97p7pg73_ahh5gqp 63qx4, verified 8 Feb 2010 at new URL]

http: / / docs.google.com/View.aspx?docid=ag9j97p7pg73_ahh5gqp63qx4

Carusi, A. (2006). Power and agency in online text-based collaborations. E-Learning and Digital Media, 3(1). http:/ / www.wwwords.co.uk/elea/content/pdfs/3/issue3_1.asp\#2

Chai, C. S. \& Khine, M. S. (2006). An analysis of interaction and participation patterns in an online community. Educational Technology E Society, 9(1), 250-261. http: / / www.ifets.info/journals/9_1/20.pdf

Cole, M. (1991). On socially shared cognitions. In L. Resnick, J. Levine \& S. Behrend (Eds.), Socially shared cognitions (pp. 398-417). Hillsdale, NJ: Lawrence Erlbaum Associates.

Cooper, M. M. (1998). Dialogic learning across disciplines. In F. Farmer (Ed.), Landmark essays on Bakhtin, rhetoric and writing: Volume 13 (pp. 81-96). Mahwah, NJ: Erlbaum.

Coppola, N. W., Hilz, S. R. \& Rotter, N. (2004). Building trust in virtual teams. IEEE Transactions on Professional Communication, 47(2), 95-104.

Davis, B. G. (1993). Collaborative learning: Group work and study teams. [viewed 12 Sep 2006] http: / / teaching.berkeley.edu/bgd/ collaborative.html

Dawes, L., Mercer, N. \& Wegerif, R. (2006). Thinking out loud: A program of activities for developing speaking, listening and thinking skills for children aged 8-11. Camberwell, Victoria: ACER Press.

de Laat, M., Chamrada, M. \& Wegerif, R. (2008). Study A8: Discourse analysis of discussion maps and the identification of pivotal dialogue moments. In C. Asterhan, R. Hever, B. Schwarz, M. Mishenkina, J. Gil, H. Penso, N. Tayer, R. de Groot, M. de Laat, R. Wegerif, M. Chamrada, A. Wichmann, A. Harrer \& U. Hoppe (Eds.), D6.2: Evaluation report on the pedagogical content of the ARGUNAUT system. http: / / www.argunaut.org/shared-space/wp6/deliverables\%20and\%20milestones/Microsoft_Word_-_d6.2final.pdf/view 
de Laat, M. \& Wegerif, R. (2007). Argunaut deliverable D5.1 - Perspectives / rules to evaluate discussions. [verified $8 \mathrm{Feb} 2010$ ]

http: / / www.argunaut.org/publications / Members / rakheli / publications / Argunaut\%20deli verable $\%$ 20D5.1\%20-\%20Perspectives-rules $\% 20$ to $\% 20$ evaluate $\% 20 \mathrm{discussions.pdf}$

Dede, C. (2004). If design-based research is the answer, what is the question? A commentary on Collins, Joseph and Bielaczyc; diSessa and Cobb; and Fishman, Marx, Blumenthal, Krajcik and Soloway in the JLS special issue on design-based research. The Journal of the Learning Sciences, 13(1), 105-114.

Dewey, J. (1910/1991). How we think. New York: Prometheus.

Dillenbourg, P. \& Jermann, P. (2006). Designing integrative scripts. In F. Fischer, I. Kollar, H. Mandl \& J. Haake (Eds.), Scripting computer-supported collaborative learning: Cognitive, computational and educational perspectives. New York: Springer.

Dirkx, J. M. \& Smith, R. O. (2004). Thinking out of a bowl of spaghetti: Learning to learn in online collaborative groups. In T. S. Roberts (Ed.), Online collaborative learning: Theory and practice. London: Information Science Publishing.

Downes, S. (2004). E-learning 2.0. Elearn Magazine: Education and Technology in Perspective. [verified 8 Feb 2010] http:/ / www.elearnmag.org/ subpage.cfm?section=articles\&article=29-1

Duron, R., Limbach, B. \& Waugh, W. (2006). Critical thinking framework for any discipline. International Journal of Teaching and Learning in Higher Education, 17(2), 160-166. [verified 8 Feb 2010] http:/ / www.isetl.org/ijtlhe/pdf/IJTLHE55.pdf

Elgort, I., Smith, A. G. \& Toland, J. (2008). Is wiki an effective platform for group course work? Australasian Journal of Educational Technology, 24(2), 195-210. http: / / www.ascilite.org.au/ajet/ajet24/elgort.html

Forte, A. \& Bruckman, A. (2007). Constructing text: Wiki as a toolkit for (collaborative?) learning. Paper presented at the OOPSLA/ACM International Symposium on Wikis (WikiSym), Montreal, Quebec, Canada. http: / / citeseerx.ist.psu.edu / viewdoc/ download?doi=10.1.1.105.5460\&rep=rep1\&type=pdf

Fountain, R. (2005). Wiki pedagogy. [verified 15 Feb 2010] http: / / www.profetic.org/dossiers / dossier_imprimer.php3?id_rubrique $=110$

Gardner, S. (1995). Inquiry is no mere conversation (or discussion or dialogue): Facilitation is hard work! Critical and Creative Thinking: The Australasian Journal of Philosophy for Children, $3(2), 38-49$.

Garrison, D. R. (1997). Computer conferencing: Cognitive and social presence issues. Paper presented at the The new learning environment: A global perspective, Proceedings of the ICDE World Conference, Pennsylvania State University.

Garrison, D. R., Anderson, T. \& Archer, W. (1999). Critical enquiry in a text-based environment: Computer conferencing in higher education. The Internet and Higher Education, 2(2-3), 87-105.

Grossera, M. M. \& Lombard, B. J. J. (2008). The relationship between culture and the development of critical thinking abilities of prospective teachers. Teaching and Teacher Education, 24(5), 1364-1375.

Guzdial, M., Ludovice, P., Realff, M., Morley, T. \& Carroll, K. (2002). When collaboration doesn't work. Paper presented at the International Conference of the Learning Sciences.

Herrington, J., McKenney, S., Reeves, T. \& Oliver, R. (2007). Design-based research and doctoral students: Guidelines for preparing a dissertation proposal. Paper presented at the Proceedings of the World Conference on Educational Multimedia, Hypermedia and Telecommunications, Chesapeake, VA.

Hron, A. \& Friedrich, H. F. (2003). A review of web-based collaborative learning: Factors beyond technology. Journal of Computer Assisted Learning, 19(1), 70-79. 
Hung, D. W. L., Chen, D.-T. \& Koh, T. S. (2006). The reverse LPP method for nurturing a community of practice. Educational Media International, 43(4), 299-314.

Hurst, D. C. \& Thomas, J. (2004). Developing team skills and accomplishing team projects online. In T. Anderson \& F. Elloumi (Eds.), Theory and practice of online learning. Athabasca University. http:/ / cde.athabascau.ca/online_book/

Koestler, A. (1969). The act of creation (Danube edition). London: Pan.

Kolb, D. A. (1984). Experiential learning: Experience as a source of learning and development. Englewood Cliffs, New Jersey: Prentice-Hall.

Kreijns, K., Kirschener, P. A. \& Jochems, W. (2003). Identifying the pitfalls for social interaction in computer-supported collaborative learning environments: A review of the research. Computers in Human Behaviour, 19, 335-353.

Laurillard, D. (1993). Rethinking university teaching: A framework for the effective use of educational technology. London: Routledge.

Laurillard, D. (2002a). Rethinking teaching for the knowledge society. Educause Review, January/February. http:/ / net.educause.edu/ir/library/pdf/erm0201.pdf

Laurillard, D. (2002b). Rethinking university teaching: A framework for the effective use of educational technology (2nd ed.). London: RoutledgeFalmer.

Lave, J. \& Wenger, E. (1991). Situated learning: Legitimate peripheral participation. New York: Cambridge University Press.

Levy, P. (2009). Inquiry-based learning: A framework. University of Sheffield: Centre for Inquirybased Learning in the Arts and Social Sciences. [viewed 28 Jan 2010] http: / / www.shef.ac.uk/ cilass/

Lipman, M. (2003). Thinking in education (2nd ed.). Cambridge: Cambridge University Press.

MacKnight, C. B. (2000). Teaching critical thinking through online discussions. Educause Quarterly, 23(1). http:/ / net.educause.edu/ir/library/pdf/EQM0048.pdf

Meeuwsen, H. J. \& Pederson, R. (2006). Group cohesion in team based learning. Mountain Rise, 3(1). http: / / www.wcu.edu/facctr/mountainrise/archive/vol3no1/html/meeuwsen.htm

Melrose, S. \& Bergeron, K. (2007). Instructor immediacy strategies to facilitate group work in online graduate study. Australasian Journal of Educational Technology, 23(1), 132-148. http: / / www.ascilite.org.au/ajet/ajet23/melrose.html

Merchant, G. (2006). Identity, social networks and online communication. E-Learning, 3(2). http: / / www.wwwords.co.uk/pdf/validate.asp?j=elea\&vol=3\&issue=2\&year=2006\&article $=$ 9_Merchant_ELEA_3_2_web

Notari, M. (2006). How to use a wiki in education: Wiki based effective constructive learning. Paper presented at the OOPSLA / ACM International Symposium on Wikis (WikiSym), Odense, Denmark. http: / / www.wikisym.org/ws2006/proceedings/p131.pdf

Oxendine, C., Robinson, J. \& Willson, G. (2004). Experiential learning. In M. Orey (Ed.), Emerging perspectives on learning, teaching and technology. http: / / projects.coe.uga.edu/epltt/index.php?title=Experiential_Learning

Palloff, R. M. \& Pratt, K. (2005). Collaborating online: Learning together in community. San Francisco: Jossey-Bass.

Pawan, F., Paulus, T. M., Yalcin, S. \& Chang, C.-F. (2003). Online learning: Patterns of engagement and interaction among in-service teachers. Language Learning $\mathcal{E}$ Technology, 7(3). http: / /lit.msu.edu/vol7num3/pdf/ pawan.pdf 
Perkins, D. N. (1993). Person-plus: A distributed view of thinking and learning. In G. Saloman (Ed.), Distributed cognitions: Psychological and educational considerations (pp. 88-110). New York: Cambridge University Press.

Piaget, J. (1962). The language and thought of the child (3rd ed.). London: Routledge \& Kegan Paul.

Piaget, J. (1972). Intellectual development from adolescence to adulthood. Human Development, $15,1-12$.

Reeves, T. (2006). Design research from a technology perspective. In J. van den Akker, K. Gravmeijer, S. McKenney \& N. Nieveen (Eds.), Educational design research (pp. 52-66). London: Routledge.

Reigeluth, C. M. (1999). Instructional-design theories and models: A new paradigm of instructional theory (Vol. 2). Mahwah, NJ: Lawrence Erlbaum Associates.

Rourke, L. \& Kanuka, H. (2009). Learning in communities of inquiry: A review of the literature. Journal of Distance Education, 23(1), 19-48.

Salmon, G. (2000). E-moderating: The key to teaching and learning online. London: Kogan Page.

Salmon, G. (2002). E-tivities: The key to active online learning. London: Kogan Page.

Scardemalia, M. \& Bereiter, C. (1996). Computer support for knowledge-building communities. In T. Koschmann (Ed.), CSCL: Theory and practice of an emerging paradigm. Mahwah, NJ: Lawrence Erlbaum Associates.

Schon, D. A. (1983). The reflective practitioner: How professionals think in action. London: Maurice Temple Smith.

Sharp, A. (2004). The other dimension of caring thinking. Critical \& Creative Thinking, 12(1), 9-14.

Stefani, L. (2004). Promoting reflective learning through the use of digital portfolios: It's the message, not the medium. Paper presented at the Conference on Supporting Student Reflection through ePortfolios, University of Newcastle, UK. 4 June.

Swan, K. (2004). Relationships between interactions and learning in online environments [viewed 24 May 2007 at http: / / www.sloan-c.org/publications/ freedownloads.asp; open access unavailable 15 Feb 2010, for an excerpt see http: / / www.yccd.edu/ documents / viewdocument.php?id=1786]

Swan, K. \& Shea, P. (2005). The development of virtual learning communities. In S. R. Hilz \& R. Goldman (Eds.), Learning together online: Research on asynchronous learning networks. Mahwah, NJ: Lawrence Erlbaum.

Swann, J. \& Sevelj, M. (2005). Mentoring and elearning: A reflection on an ASCILITE CMP relationship. In Balance, fidelity, mobility: Maintaining the momentum. Proceedings ASCILITE Brisbane 2005.

http: / / www.ascilite.org.au/conferences / brisbane05/blogs/proceedings / P8_Swann.pdf

$\mathrm{Tu}, \mathrm{C}$-H. (2002). The measurement of social presence in an online learning environment. International Journal on E-Learning, (April-June). [verified 15 Feb 2010] http: / / www.thefreelibrary.com/ The+measurement+of+social+presence+in+an+online+lear ning+environment-a090933922

van den Akker, J. (1999). Principles and methods of development research. In J. van den Akker, N. Nieveen, R. M. Branch, K. L. Gustavson \& T. Plomp (Eds.), Design methodology and developmental research in education and training (pp. 1-14). Dordrecht, Netherlands: Kluwer.

Vygotsky, L. S. (1986). Thought and language (A. Kozulin, Trans.). Cambridge Mass: MIT Press.

Wang, F., \& Hannafin, M. J. (2005). Design-based research and technology-enhanced learning environments. Educational Technology Research and Development, 53(4), 5-23. 
Weaver, C. \& Albion, P. (2005). Momentum in online discussions: The effect of social presence on motivation for participation. In Balance, fidelity, mobility: Maintaining the momentum. Proceedings ASCILITE Brisbane 2005. http: / / www.ascilite.org.au / conferences / brisbane05/blogs / proceedings / 81_Weaver.pdf

Wegerif, R. (2007). Dialogic education and technology: Expanding the space of learning. New York: Springer.

Wegerif, R., Chamrada, M., de Laat, M., Williams, M., Mansour, N. \& Hever, R. (2008). Argunaut deliverable D5.2: Patterns of interaction and intervention rules. [verified 15 Feb 2010] http: / / www.argunaut.org/publications / publications / argunaut-publications

Wenger, E. (1998). Communities of practice: Learning, meaning, and identity. New York: Cambridge University Press.

Weterman, F. (2004). Supporting virtual learning groups: A response to the plea for experiential learning [Electronic version]. Focus(1) [not found 15 Feb 2010]

Williams, B. (2003). Participation in on-line courses - how essential is it? [viewed 5 Oct 2004 at http:/ / ifets.ieee.org/dicussions/discuss_january2004; verified 15 Feb 2010 at new URL] http://www.ifets.info/journals/7_2/1.pdf

Wilson, B. G., Ludwig-Hardman, S., Thornam, C. L. \& Dunlap, J. C. (2004). Bounded community: Designing and facilitating learning communities in formal courses. Paper presented at the American Educational Research Association Meeting. [viewed 24 Apr 2008, verified 15 Feb 2010] http: / / carbon.cudenver.edu/ bwilson/BLCs.html

Wise, L. \& Quealy, J. (2006). At the limits of social constructivism: Moving beyond LMS to reintegrate scholarship. In Who's learning? Whose technology? Proceedings ascilite Sydney 2006. http:// ascilite.org.au/conferences / sydney06/proceeding/pdf_papers/p158.pdf

This is an expanded version of article which received an Outstanding Paper Award at ascilite Auckland 2009. The reference for the conference version is:

Swann, J. (2009). A dialogic approach to online facilitation. In Same places, different spaces. Proceedings ascilite Auckland 2009.

http: / / www.ascilite.org.au/conferences/auckland09/procs/swann.pdf

Author: Jennie Swann, Flexible Learning Advisor, Centre for Learning and Teaching, Auckland University of Technology, New Zealand. Email: jennie.swann@aut.ac.nz

Please cite as: Swann, J. (2010). A dialogic approach to online learning. Australasian Journal of Educational Technology, 26(1), 50-62.

http://www.ascilite.org.au/ajet/ajet26/swann.html 